\title{
ANALISIS EFEKTIFITAS DAN PERTUMBUHAN PENDAPATAN ASLI DAERAH PADA DINAS PENDAPATAN DAERAH KOTA MAKASSAR
}

\author{
Idrawahyuni \\ Program Studi Akuntansi \\ Fakultas Ekonomi dan Bisnis \\ Universitas Muhammadiyah Makassar \\ e-mail: idrawahyuni.idris@gmail.com
}

\begin{abstract}
Abstrak
Penelitian ini bertujuan untuk mengetahui efektivitas dan pertumbuhan pendapatan asli daerah pada Dinas Pendapatan Daerah Kota Makassar. Jenis penelitian ini adalah deskriptif kuantitatif. Data yang digunakan adalah data sekunder berupa laporan keuangan Dinas Pendapatan Daerah Kota Makassar dengan periode pengukuran lima tahun terakhir yaitu laporan keuangan tahun 2013 sampai 2017. Teknik analisis data menggunakan analisis perhitungan secara kuantitatif efektivitas dan pertumbuhan PAD dengan menggunakan metode analisis rasio. Hasil analisis data menggunakan rasio efektivitas dan pertumbuhan pendapatan asli daerah, yang menunjukkan bahwa dari kedua analisis rasio keuangan yang dilakukan tergolong efektif.
\end{abstract}

\section{Kata Kunci : Efektivitas, Pertumbuhan Pendapatan Asli Daerah.}

This study aims to determine the effectiveness and growth of local revenue at the Makassar City Regional Revenue Service. This type of research is descriptive quantitative. The population of this study is the financial statements of the Makassar City Regional Revenue Service. Samples were taken from the financial statements of the Makassar City Regional Revenue Service office in the last five years, from 2013 to 2017. The results of data analysis used the ratio of effectiveness and growth of local revenue, which showed that the two financial ratio analyzes were classified as effective.

Keywords: Effectiveness, Growth of Original Regional Revenue.

\section{PENDAHULUAN}

Pemerintah daerah berhak menetapkan peraturan daerah dan peraturan-peraturan lain untuk melaksanakan otonomi daerah dan tugas pembantuan. Tiap-tiap daerah mempunyai hak dan kewajiban mengatur dan mengurus sendiri urusan pemerintahannya untuk meningkatkan efisiensi dan efektivitas penyelenggaraan pemerintahan dan pelayanan kepada masyarakat.

Pengelolaan dan pertanggungjawaban keuangan daerah telah ditetapkan pada Peraturan Pemerintah Pasal 4 No.105 Tahun 2000 yang menegaskan bahwa pengelolaan keuangan daerah harus dilakukan secara tertib, taat pada peraturan perundang-undangan yang berlaku, efisien, efektif, transparan, dan bertanggung jawab dengan memperhatikan atas keadilan dan kepatuhan. Apabila pengelolaan keuangan daerah dilakukan dengan baik sesuai dengan peraturan yang telah ditetapkan, maka tentunya akan meningkatkan kinerja pemerintah daerah itu sendiri. 
Pengukuran kinerja penting dilakukan untuk dapat menilai akuntabilitas pemerintah daerah dalam pengelolaan pendapatan daerah dan dituangkan dalam bentuk laporan keuangan yang bertujuan untuk menyajikan informasi mengenai posisi keuangan, realisasi anggaran, serta kinerja keuangan pemerintah daerah yang berguna dalam pengambilan keputusan dan untuk menunjukkan akuntabilitas pelaporan atas sumber daya yang dikelola pemerintah. Bentuk dari penilaian kinerja tersebut berupa analisis rasio keuangan yang berasal dari unsur Laporan Pertanggungjawaban Kepala Daerah berupa perhitungan APBD (Puspitasari, 2013).

Pemerintah daerah diharapkan dapat mengelola sumber daya yang dimilikinya dan melaksanakan tata kelola pemerintahan yang baik sehingga akan berdampak pada pelayanan yang diberikan kepada masyarakat. Berkaitan dengan hal tersebut, maka pemerintah daerah harus pandai dalam menyelenggarakan pemerintahannya sehingga tercipta tata kelola pemerintahan yang baik serta adanya evaluasi yang berkala atas capaian pemerintah daerah dalam kurun waktu tertentu. Pengukuran kinerja merupakan salah satu cara yang dapat digunakan pemerintah daerah dalam mencapai pemerintahan yang baik.

Pengukuran kinerja merupakan komponen yang penting karena akan memberikan umpan balik atas rencana yang telah diimplementasikan. Fungsi dari pengukuran kinerja dapat menjelaskan mengenai evaluasi bagaimana program tersebut berjalan, sarana perbandingan atas pelayanan yang diberikan dan alat komunikasi dengan publik Pengukuran kinerja keuangan daerah adalah sesuatu yang penting untuk dilakukan. Pernyataan ini selaras dengan salah satu kunci sukses dari pembaharuan dalam sektor publik adalah dengan melakukan pengukuran kinerja.

Pemberian otonomi kepada daerah memungkinkan daerah yang bersangkutan untuk mengatur serta meningkatkan daya guna dan hasil guna penyelenggaraan pemerintahan dalam rangka pelayanan terhadap masyarakat. Untuk dapat menyelenggarakan otonomi daerah yang optimal, maka diperlukan dana yang cukup. Sebagian dana tersebut diusahakan oleh daerah sendiri, yaitu berupa Pendapatan Asli Daerah yang mencukupi kepentingan rumah tangganya sendiri. Suatu daerah yang mempunyai Pendapatan Asli Daerah yang cukup, akan dengan mudah memenuhi kebutuhan rumah tangganya dan semata-mata demi terciptanya kemakmuran rakyat (Prakosa, 2005:145).

Daerah kabupaten dan kota memiliki kewenangan yang utuh kecuali di bidang pertahanan, keamanan, peradilan, politik luar negeri, moneter dan agama. Dalam rangka pelaksanaan kewenangan pemerintah daerah sebagaimana ditetapkan dalam Undang-undang No 32 Tahun 2004 tentang Pemerintah Daerah yang diikuti dengan Undang-undang No 233 Tahun 2004 tentang perimbangan Keuangan antara Pemerintah Pusat dan Daerah, timbul hak dan kewajiban daerah yang dapat dinilai dengan uang, sehingga perlu dikelola dalam pengelolaan keuangan daerah.

Selanjutnya, untuk meningkatkan efektivitas pengawasan pungutan daerah, mekanisme pengawasan diubah dari represif menjadi preventif yaitu setiap peraturan daerah tentang pajak dan retribusi sebelum dilaksanakan harus mendapat persetujuan terlebih dahulu dari pemerintah pusat. Selain itu, terhadap daerah yang menetapkan kebijakan di bidang pajak daerah yang melanggar ketentuan peraturan perundang-undangan yang lebih tinggi akan dikenakan sanksi berupa penundaan dan/atau pemotongan dana alokasi umum dan/atau dana bagi hasil atau restitusi.Berdasarkan uraian diatas, maka yang menjadi 
permasalahan dalam artikel ini adalah bagaimana tingkat efektivitas dan pertumbuhan PAD pada Dinas Pendapatan Daerah Kota Makassar.

\section{METODE PENELITIAN}

Rancangan dalam penelitian ini menggunakan penelitian deskriptif dengan pendekatan kuantittaif. Jenis data yang digunakan adalah jenis dari sekunder.Teknik analisis dalam penelitian ini menggunakan analisis rasio untuk mengetahui tingkat efektivitas dan pertumbuhan PAD Kota Makassar. Proses penelitian ini diawali dengan pengambilan data yang meliputi data target dan realisasi penerimaan PAD. Data yang sudah terkumpul dilakukan proses berikutnya yaitu perhitungan secara kuantitatif efektivitas dan pertumbuhan PAD dengan menggunakan metode analisis rasio, disajikan dalam bentuk tabel dan grafik. Hasil analisis kemudian dideskripsikan untuk menjelaskan tingkat efektivitas dan pertumbuhan PAD Kota Makassar periode 2013-2017.

\section{HASIL DAN PEMBAHASAN \\ Hasil}

Sesuai dengan tujuan penelitian ini yaitu untuk mengetahui efektivitas dan pertumbuhan PAD pada Dinas Pendapatan Daerah Kota Makassar maka, hasil dan pembahasan melingkupi realisasi dan target penerimaan PAD pada Dinas Pendapatan Daerah Kota Makassar dari pungutan pajak daerah dan retribusi daerah Kota Makassar. Berikut uraian mengenai hasil penelitian antara lain:

\section{Sumber Pendapatan Daerah Kota Makassar}

a. Pajak Daerah dan Sistem Pemungutan Pajak Daerah Kota Makassar

Pajak Daerah adalah iuran yang wajib dilakukan oleh Orang Pribadi atau Badan kepada Daerah tanpa imbalan langsung yang seimbang, yang dapat dipaksakan berdasarkan peraturan perundang-undangan yang berlaku, yang digunakan untuk membiayai penyelenggaraan pemerintahan daerah dan pembangunan daerah.

Pemungutan pajak itu bisa dilakukan secara dibayar sendiri oleh Wajib Pajak (self assessment) yaitu untuk jenis Pajak Hote, Pajak Restoran, Pajak Hiburan, Pajak Parkir, Pajak Penerangan Jalan, Pajak Bahan Bakar Kendaraan Bermotor, Bea Perolehan Hak Atas Tanah dan Bangunan dan Pajak Rokok.

Untuk Pajak yang ditetapkan oleh Kepala Daerah (official assessment) yaitu untuk jenis Pajak Kendaraan Bermotor, Bea Balik Nama Kendaraan Bermotor, Pajak Air Tanah Pajak Reklame dan Pajak Bumi dan Bangunan Perdesaan dan Perkotaan Pemungutan Pajak terutang dengan cara dibayar sendiri oleh Wajib Pajak (self assessment) merupakan pembayaran Pajak terutang oleh Wajib Pajak.

b. Retribusi Daerah dan Sistem Pemungutan Retribusi Daerah Kota Makassar

Retribusi adalah pungutan Daerah sebagai pembayaran atas jasa atau pemberian izin tertentu yang khusus disediakan dan/atau diberikan oleh Pemerintah Daerah untuk kepentingan orang pribadi atau Badan. Menurut Undang-undang Nomor 28 Tahun 2009 tentang Pajak Daerah dan Retribusi Daerah, Retribusi digolongkan menjadi 3 yaitu :

1) Retribusi Jasa Umum yaitu pelayanan yang disediakan atau diberikan Pemerintah Daerah untuk tujuan kepentingan dan kemanfaatan umum serta dapat dinikmati oleh orang pribadi atau Badan. 
2) Retribusi Jasa Usaha yaitu pelayanan yang disediakan oleh Pemerintah Daerah dengan menganut prinsip komersial.

3) Retribusi Perizinan Tertentu yaitu pelayanan perizinan tertentu oleh Pemerintah Daerah kepada orang pribadi atau badan yang dimaksudkan untuk pengaturan dan pengawasan atas kegiatan pemanfaatan ruang, penggunaan sumber daya alam, barang, prasarana, sarana atau fasilitas tertentu guna melindungi kepentingan umum dan menjaga kelestarian lingkungan.

Pelaksanaan pemungutan retribusi daerah dapat dilaksanakan dengan menggunakan Karcis/tanda bukti pembayaran retribusi kartu(tanda bukti pembayaran retribusi dibubuhkan/ditempelkan pada kartu) dan Surat Ketetapan (tanda bukti pembayaran retribusi dibubuhkan/ditempelkan pada Surat Ketetapan).

c. Sumber Dana Perimbangan Daerah Kota Makassar

Dana Perimbangan adalah dana yang bersumber dari pendapatan APBN yang dialokasikan kepada daerah (otonom) untuk mendanai kebutuhan daerah dalam rangka pelaksanaan Desentralisasi. Jumlah Dana Perimbangan ditetapkan setiap tahun anggaran dalam APBN. Dana perimbangan terdiri dari dana bagi hasil, dana alokasi khusus dan dana alokasi umum.

Salah satu sumber pendapatan daerah Kota Makassar yaitu dana bagi hasil yang berasal dari pajak terdiri dari Pajak Bumi dan Bangunan (PBB), Bea Perolehan Hak atas Tanah dan Bangunan (BPHTB), dan Pajak Penghasilan (PPh) Pasal 25 dan Pasal 29 Wajib Pajak Orang Pribadi Dalam Negeri dan PPh Pasal 21.

Pajak dan retribusi daerah merupakan sumber penerimaan yang potensial di Kota Makassar, hal ini dapat dilihat dari perkembangan pajak daearah, retribusi daerah, dan pendapatan asli daerah, yang ditunjukan pada Tabel 1 berikut:

Tabel 1

Perkembangan Penerimaan PAD Kota Makassar Tahun 2013-2017

\begin{tabular}{|c|l|l|l|}
\hline Tahun & $\begin{array}{c}\text { Pajak Daerah } \\
(\mathbf{R p})\end{array}$ & $\begin{array}{c}\text { Retribusi } \\
\text { Daerah } \\
(\mathbf{R p})\end{array}$ & \multicolumn{1}{|c|}{ PAD } \\
\hline 2013 & 518.706 .710 .508 & 7.801 .477 .003 & 612.056 .765 .277 \\
\hline 2014 & 61.684 .151 .010 & 8.109 .845 .648 & 655.362 .121 .024 \\
\hline 2015 & 635.647 .206 .877 & 9.101 .781 .365 & 709.962 .895 .492 \\
\hline 2016 & 759.202 .412 .170 & 10.730 .746 .003 & 879.579 .142 .506 \\
\hline 2017 & 938.796 .977 .770 & 10.880 .816 .325 & 949.677 .794 .095 \\
\hline Rata-rata & 682.807 .491 .667 & 9.324 .933 .269 & 61.327 .743 .679 \\
\hline
\end{tabular}

Sumber: Data Sekunder DISPENDA Kota Makassar Tahun 2018

\section{Analisis Rasio Efektivitas PAD Kota Makassar (X)}

Rasio Efektivitas menggambarkan kemampuan pemerintah daerah dalam merealisasikan pendapatan asli daerah yang direncanakan dibandingkan dengan target yang ditetapkan berdasarkan potensi riil daerah. Semakin tinggi rasio efektivitas, menggambarkan kemampuan daerah yang semakin baik. Untuk mengetahui tingkat efektivitas, dapat dilihat dari tingkat efektivitas keuangan daerah yang bersumber dari 
pemungutan pajak dan retribusi daerah terhadap penerimaan Pendapatan Asli Daerah (PAD) Kota Kakassar, dapat dilihat pada tabel berikut:

$$
\text { Rasio Efektivitas } P A D=\frac{\text { Realisasi Penerimaan } P A D}{\text { Target Penerimaan } P A D} \times 100 \%
$$

Tabel 2

Efektivitas PAD Kota Makassar

\begin{tabular}{|c|c|c|c|}
\hline Tahun & $\begin{array}{c}\text { Target Penerimaan } \\
\text { PAD } \\
\text { (Rp) }\end{array}$ & $\begin{array}{c}\text { Realisasi Penerimaan } \\
\text { PAD } \\
(\mathbf{R p )}\end{array}$ & $\begin{array}{c}\text { Rasio } \\
\text { Efektivitas }\end{array}$ \\
\hline 2013 & 546.863 .198 .000 & 612.056 .765 .277 & $112 \%$ \\
\hline 2014 & 750.506 .544 .000 & 655.362 .121 .024 & $87 \%$ \\
\hline 2015 & 904.432 .575 .000 & 709.962 .895 .492 & $78 \%$ \\
\hline 2016 & 1.193 .018 .343 .000 & 879.579 .142 .506 & $74 \%$ \\
\hline 2017 & 1.086 .139 .148 .000 & 949.677 .794 .095 & $87 \%$ \\
\hline Rata- rata & 896.191 .961 .600 & 761.327 .743 .679 & $88 \%$ \\
\hline
\end{tabular}

Sumber: Data Sekunder DISPENDA Kota Makassar Tahun 2018 (Data Diolah)

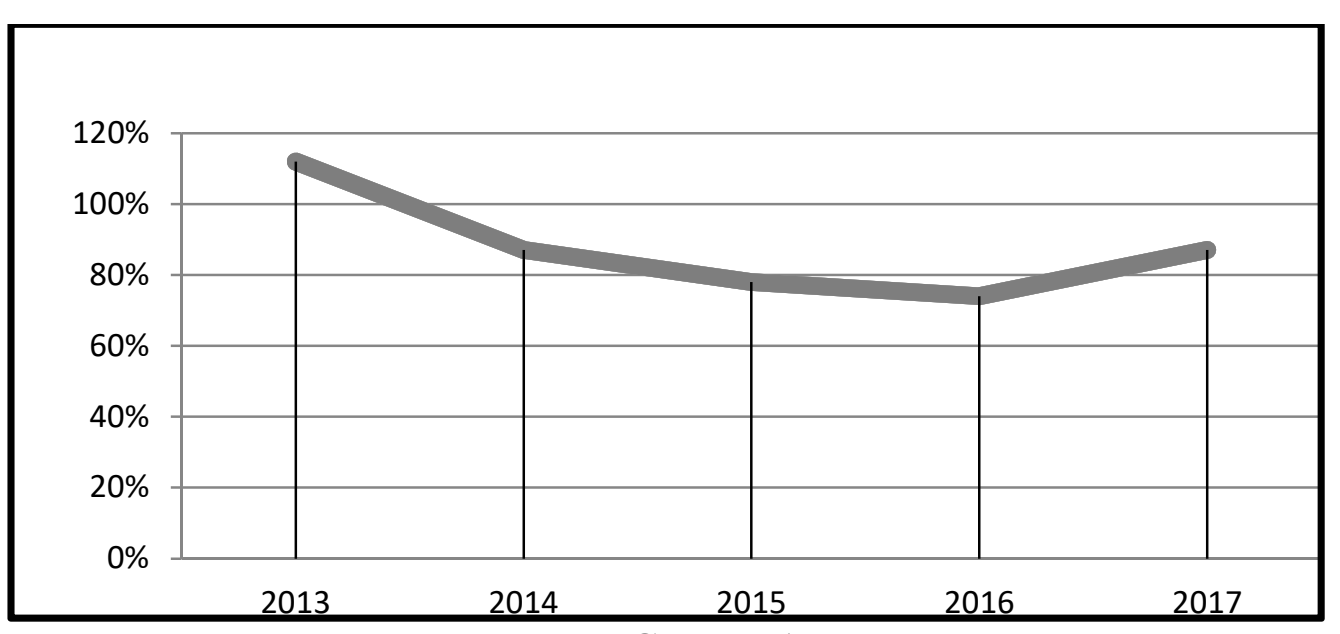

Gambar 1

Efektivitas PAD Kota Makassar

Pada tabel dan grafik diatas menggambarkan efektivitas PAD Kota Makassar yang dilihat dari rasio efektivitas PAD Kota Makassar tahun 2013-2017. Tingkat efektivitas penerimaan pendapatan asli daerah pada tahun 2013, 2014, 2015, 2016 dan 2017 masingmasing sebesar $112 \%, 87 \%, 78 \%, 74 \%$, dan $87 \%$ mencerminkan penerimaan yang berfluktuasi.

Tabel 3 


\begin{tabular}{|c|c|}
\hline Diatas $100 \%$ & Sangat Efektif \\
\hline $90 \%-100 \%$ & Efektif \\
\hline $80 \%-90 \%$ & Cukup Efektif \\
\hline $70 \%-80 \%$ & Kurang Efektif \\
\hline $60 \%-70 \%$ & Tidak fektif \\
\hline
\end{tabular}

\section{Efektivitas PAD Kota Makassar}

Sumber : Depdagri, Kepmendagri Nomor 690.900.327 Tahun 1996. Pedoman Penilaian Kinerja Keuangan

Realisasi penerimaan pendapatan asli daerah lebih besar dibandingkan dengan target penerimaan pendapatan asli daerah yang telah ditetapkan. Berdasarkan tabel di atas secara keseluruhan penerimaan dari pendapatan asli daerah menggambarkan kinerja yang baik dan apabila dilihat dari penggolongan tingkat efektivitas, penerimaan pendapatan asli daerah Kota Makassar tahun 2013-2017 tergolong cukup efektif yaitu rata-rata 88\%.

Dari pengamatan data sekunder Dinas Pendapatan Daerah Kota Makassar dari tahun 2013-2017, maka peneliti menyimpulkan bahwa efektivitas PAD kota Makassar tergolong kurang efektif. Namun persentase efektivitas masih perlu ditingkatkan lagi, dengan kata lain apabila Pemerintah Daerah Kota Makassar lebih mengoptimalkan penerimaan pajak dan retribusi daerah berdasarkan potensi yang ada dan bisa dikembangkan, maka persentase efektivitas PAD Kota Makassar sebaiknya lebih ditingkatkan untuk tahun berikutnya.

\section{Pertumbuhan PAD Kota Makassar (Y)}

Berdasarkan angka dari hasil pendapatan asli daerah Kota Makassar tahun 2013-2017, maka peningkatan pendapatan daerah dari tahun ke tahun dapat dilihat dari dari tabel berikut:

$$
\text { Rasio pertumbuhan } P A D=\frac{P A D t 1-P A D t 0}{P A D t 0} \times 100 \%
$$

\section{Tabel 4}

Pertumbuhan PAD Kota Makassar

\begin{tabular}{|c|c|c|c|c|}
\hline Tahun & $\begin{array}{c}\text { PAD t0 } \\
\text { (Rp) }\end{array}$ & $\begin{array}{c}\text { PAD t1 } \\
\text { (Rp) }\end{array}$ & $\begin{array}{c}\text { PAD t1- PADt0 } \\
\text { (Rp) }\end{array}$ & $\begin{array}{c}\text { Tingkat } \\
\text { Pertumbuhan }\end{array}$ \\
\hline $2012-2013$ & 556.202 .758 .215 & 612.056 .765 .277 & 55.854 .007 .062 & $10 \%$ \\
\hline $2013-2014$ & 612.056 .765 .277 & 655.362 .121 .024 & 43.305 .355 .747 & $7 \%$ \\
\hline $2014-2015$ & 655.362 .121 .024 & 709.962 .895 .492 & 54.600 .774 .468 & $8 \%$ \\
\hline $2015-2016$ & 709.962 .895 .492 & 879.579 .142 .506 & 169.616 .247 .014 & $24 \%$ \\
\hline $2016-2017$ & 879.579 .142 .506 & 949.677 .794 .095 & 70.098 .651 .589 & $8 \%$ \\
\hline
\end{tabular}

Sumber: Data Sekunder DISPENDA Kota Makassar Tahun 2018 (DataDiolah) 


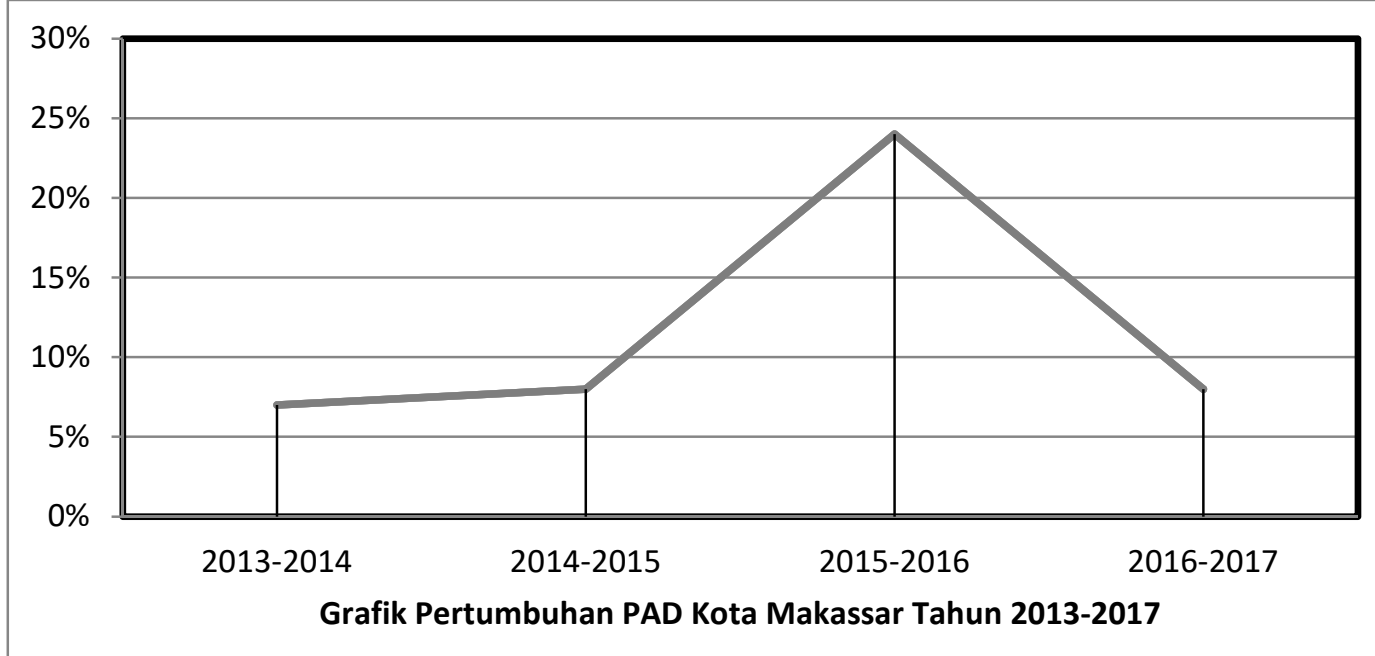

\section{Gambar 2}

Pertumbuhan PAD Kota Makassar Tahun 2013-2017

Pada tabel dan grafik di atas menggambarkan rasio pertumbuhan pendapatan asli daerah Kota makassar, hanya ada satu periode dalam lima tahun terakhir. Berdasarkan data sekunder yang di analisis oleh peneliti dengan menggunakan rasio petumbuhan PAD Kota Makassar tahun 2013-2017, yaitu dari tahun 2013-2014 sebesar 7\% naik sebesar 1\% menjadi 8\% pada rahun 2014-2015. Pada tahun 2015-2016 mengalami peningkatan yang cukup tinggi sebesar $16 \%$ menjadi $24 \%$, sedangkan pada tahun 2016-2017 mengalami penurunan sebesar $16 \%$ menjadi $8 \%$. Jadi bisa di katakan selama lima tahun ini terus terjadi peningkatan dan penurunan di rasio pertumbuhan tapi jika di bandingkan dengan tahun pertama rasio pertumbuhan jauh lebih baik dilihat dari angka pendapatan asli daerah Kota Makassar.

\section{Pembahasan}

Berdasarkan hasil analisis yang telah diuraikan di atas diperoleh hasil bahwa tingkat efektivitas penerimaan PAD Kota Makassar dari tahun 2013-2017 mencerminkan penerimaan pendapatan yang tergolong efektif. Pada tahun 2013 realisasi penerimaan pendapatan asli daerah Kota Makassar lebih besar dibandingkan dengan target 74 penerimaan pendapatan asli daerah, sehingga tingkat efektivitasnya mencapai 112\%. Pada tahun 2014 realisasi penerimaan pendapatan asli daerah Kota Makassar lebih kecil dibandingkan dengan target penerimaan pendapatan asli daerah, sehingga tingkat efektivitasnya menurun senilai 87\%. Pada tahun 2015 realisasi penerimaan pendapatan asli daerah Kota Makassar lebih kecil dibandingkan dengan target penerimaan pendapatan asli daerah, sehingga tingkat efektivitasnya menurun senilai $78 \%$. Pada tahun 2016 realisasi penerimaan pendapatan asli daerah Kota Makassar lebih kecil dibandingkan dengan target penerimaan pendapatan asli daerah, sehingga tingkat efektivitasnya menurun senilai 74\%. Pada tahun 2017 realisasi penerimaan pendapatan asli daerah Kota Makassar lebih kecil dibandingkan dengan target penerimaan pendapatan asli daerah, sehingga tingkat efektivitasnya menurun senilai $87 \%$. Dilihat dari hasil efektivitas tersebut yang mengalami kenaikan dan penurunan, maka dapat disimpulkan bawah hl ini disebabkan karena penerimaan realisasi penerimaan pendapatan asli daerah lebih besar dibandingkan dengan target penerimaan pendapatan asli daerah yang telah ditetapkan. 
Petumbuhan pendapatan daerah Kota Makassar dari tahun 2013-2017 juga mengalami kenaikan dan penurunan. Pada tahun 2012-2013 pertumbuhan pendapatan asli daerah meningkat hingga 10\%. Pada tahun 2013-2014 pertumbuhan pendapatan asli daerah meningkat hingga 7\%. Pada tahun 2014-2015 pertumbuhan pendapatan asli daerah meningkat hingga 8\%. Pada tahun 2015-2016 pertumbuhan pendapatan asli daerah meningkat hingga 24\%. Pada tahun 2016-2017 pertumbuhan pendapatan asli daerah meningkat hingga 8\%. Peningkatan pendapatan daerah Kota Makassar tertinggi dari tahun ketahun terletak di tahun 2015-2016.

Berdasarkan dari hasil analisis rasio pertumbuhan PAD Kota Makassar terjadi peningkatan dan penurunan setiap tahunnya. Namun hal ini masih tergolong normal karena tidak terdapat penurunan yang drastis. Hasil penelitian ini didukung dengan penelitian Ritno $\mathrm{H}$. Rondonuwu (2015) dengan hasil penelitian yang tergolong efektif, namun tidak sejalan dengan penelitian Hendro Sumarjo (2010) dengan hasil yang tidak efektif.

\section{KESIMPULAN}

Berdasarkan penjelasan dari hasil penelitian mengenai Analisis efektivitas dan pertumbuhan PAD Kota Makassar, maka kesimpulan yang diperoleh yaitu, tingkat efektivitas dan pertumbuhan PAD tergolong efektif. Hal ini dapat dilihat dari penerimaan realisasi lebih besar dibandingkan dengan target dan pertumbuhan PAD setiap tahunnya yang mengalami kenaikan dan penurunan masih tergolong normal karena tidak terdapat tingkat penurunan yang drastis.

\section{SARAN}

Untuk menciptakan peningkatan pendapatan daerah yang tinggi, maka diperlukan kinerja pemerintah yang maksimal. Dengan ini peneliti menyampaikan saran berikut:

1. Untuk pemerintah daerah diharapkan mampu mengelola dan memaksimalkan sumber daya yang ada dan untuk lebih meningkatkan secara maksimal penerimaan pajak dan retribusi daerah agar pendapatan asli daerah terus meningkat.

2. Untuk peneliti selanjutnya maka saran yang dapat diberikan untuk menambahkan variabel lainnya rasio kemandirian, rasio efisiensi dan rasio kinerja keuangan lainnya, untuk mendapatkan generalisasi yang lebih baik.

\section{DAFTAR PUSTAKA}

Adhiantoko, Hony. 2013. Analisis Kinerja Keuangan pemerintah Daerah Kabupaten Blora tahun 2007-2011. Jurnal Akuntansi. Vol.1, No. 1.

Armstrong, M. 1998. Performance Management. Clays, Ltd. St. Ives Ple. England.

Aulia, Zikri. 2017. Analisis Kinerja Keuangan Pemerintah Daerah Kabupaten Aceh Timur Periode 2011-2015. Jurnal Akuntansi. Vol.1, No. 1. Dwiyanto, Agus. 2002. Reformasi Birokrasi Publik di Indonesia. UGM: Yogyakarta.

Faisol, Ahmad. 2013. Analisis Kinerja Keuangan Bank Pada PT Bank Muamalat Indonesia Tbk. Jurnal Ilmiah Berkala Empat Bulanan. Vol. 3, No.2.

Gibson, James L., John M. Ivancevich dan James H. Donnelly, Jr. 1994. Organisasi dan Manajemen. Perilaku, Struktur, Proses. Edisi keempat. Jakarta: Erlangga. 
Hadiati, Sri., dan Ruci, Sarwi. 2007. Analisis Kinerja Kualitas Pelayanan Terhadap KepuasanPelanggan pada Telkomsel Malang Area. Jurnal Manajemen dan Kewirausahaan. Vol. 3, No. 2.

Halim, Abdul. 2012. Akuntansi Keuangan Daerah. Salemba Empat: Jakarta. Idrus, Muhammad. 2009. Metode Penelitian Ilmu Sosial. Erlangga: Yogyarkarta.

Hersey, Paul, Blanchard, Kenneth H. 1993. Management for Organizational Behavior. Edisi 6: Singapore.

Julastiana, Y., \& Suartana, I. W. (2012). Analisis Efisiensi dan Efektivitas Penerimaan Pendapatan Asli Daerah Kabupaten Klungkung. Download: http://www. google. com. Diakses tanggal, 17.

Julitawati, Ebit. 2012. Pengaruh Pendapatan Asli Daerah dan Dana Perimbangan Terhadap Kinerja Keuangan Pemerintah Kabupaten/Kota di Provinsi Aceh. Jurnal Akuntansi. Vol. 1, No. 1.

Kusuma, Md Karisna Arta Anggar. 2013. Analisis Pengaruh Penerimaan Pajak Daerah dan Retribusi Daerah Terhadap Peningkatan PAD Sekabupaten/Kota Provinsi Bali. E-Jurnal Akuntansi Udayana. Vol. 5, No. 3.

Mahmudi. 2007. Manajemen Kinerja Sektor Publik. Edisi 3. UPP STIM YKPN.

Mulyadi. 2001. Akuntansi Manajemen: Konsep, Manfaat dan Rekayasa. Edisi III. Salemba Empat: Jakarta.

Mardiasmo. 2002. Otonomi dan Manajemen Keuangan Daerah. Andi: Yogyakarta.

Mardiasmo. 2005. Akuntansi Sektor Publik. Edisi 2. Andi: Yogyakarta.

Mulyadi. 2001. Sistem Akuntansi. Edisi Tiga. Salemba Empat: Jakarta. Prakosa, Kesit. 2005, Pajak dan Retribusi Daerah. Edisi Revisi. UII. Press. Yogyakarta.

Pramono, Joko. 2014. Analisis Rasio Keuangan Untuk Menilai Kinerja Keuangan Pemerintah Daerah. Among Makarti. Vol.7, No.13.

Puspitasari, E. R. A., \& Rohman, A. (2014). Analisis efektivitas, efisiensi, dan Kontribusi pajak dan retribusi Daerah terhadap pad kabupaten Blora tahun 2009- 2013 (Doctoral dissertation, Fakultas Ekonomika dan Bisnis).

Ronald, Andreas. dan Sarmiyatiningsih, Dwi. 2010. Analisis Kinerja Keuangan dan Pertumbuhan Ekonomi Sebelum dan Sesudah Diberlakukannya Otonomi Daerah di Kabupaten Kulon Progo. Jurnal Bisnis dan Ekonomi. Vol. 1, No. 1.

Rondonuwu, R. H., Tinangon, J. J., \& Budiarso, N. (2016). Analisis Efisiensi Dan Efektivitas Pengelolaan Keuangan Daerah Pada Dinas Pendapatan Daerah Kabupaten Minahasa. Jurnal EMBA: Jurnal Riset Ekonomi, Manajemen, Bisnis dan Akuntansi, 3(4).

Rudiyanto, Muhamad. 2015. Analisis Kinerja Keuangan Serta Kemampuan Keuangan Pemerintah Daerah dalam Pelaksanaan Otonomi Daerah. Jurnal Akuntansi. Vol.1, No. 1. Sijabat, Mentari Yosephen. 
Saleh, Choirul. dan Wachid, Abdul. 2012. Analisis Kinerja Keuangan dan Kemampuan Keuangan Pemerintah daerah dalam Pelaksanaan Otonomi Daerah (Studi pada Dinas Pendapatan Daerah dan Badan Pengelola Keuangan dan Aset Daerah Kota Malang Tahun Anggaran 2008-2012). Jurnal Administrasi Publik (JAP). Vol. 2 , No. 2.

Sugiyono. 2006. Metode Penelitian Kuantitatif dan R\&D. Alfabeta: Bandung.

Sugiyono. 2005. Metode Penelitian Bisnis. Alfabeta:Bandung.

Ahmad Falah. 2010. Analisis Kinerja Dengan Pendekatan Balanced Scorecard Pada PDAM Kabupaten Semarang. Jurnal Manajemen dan Kewirausahaan. Vol.1, No. 1.

Susanto, Hery. 2010. Evaluasi Pemerintah Daerah Provinsi Nusa Tenggara Barat Tahun Anggaran 2003-2007. Ganec Swara Edisi Khusus. Vol. 4, No.3.

Sutrisno. 2009. Manajemen Keuangan Teori, Konsep dan Aplikasi. Edisi I. Ekonisia: Yogyakarta.

Yunardi, Febrina. 2010. Analisis Kinerja Keuangan Pemerintah Daerah Kabupaten Kuantan Singingi. Mahasiswa Fakultas Ekonomi Universitas Riau.

Wenny, Cherrya Dhia. 2012. Analisis Pengaruh Pendapatan Asli Daerah Terhadap Kinerja Keuangan Pada Pemerintah Kabupaten dan Kota Di Provinsi Sumatera Selatan. Jurnal Ilmiah STIE MDP. Vol. 1, No.2. 